\title{
Women and War Zones: May Sinclair's Personal Negotiation with the First World War
}

\author{
Laurel Forster
}

\begin{abstract}
May Sinclair's emotionally-charged journal recording her short time near the Belgian front lines offers a highly personalised account of a female presence in war. This essay explores the roles performed and the spaces encountered by Sinclair and the other women she met. Women's complex relationship with war zones, spaces and places is revealed through personal experience, masculine attitudes in evidence and Sinclair's own modernist writerly techniques.
\end{abstract}

Keywords: May Sinclair, World War I, Women's work at the front line, access to the front for women, women writers of WW1, interior and exterior war zones, psychological responses to WW1, shell shock, war reporting, Sinclair's war novels and poetry, critics' views of Sinclair's writing.

\begin{abstract}
I make no apology for my many errors - where they were discoverable I have corrected them in a foot-note; to this day I do not know how wildly wrong I may have been about kilometres and the points of the compass, and the position of batteries and the movements of armies; but there were other things of which I was dead sure; and this record has at least the value of a "human document". (Sinclair, 1915a: x-xi)
\end{abstract}

Women were active participants in the various spaces of the First World War, at home and at the front; this is now well understood through writings and other documents (Ouditt 2000). However, much less readily understood are issues such as the conditions of their placement; the difficulties they experienced; the level of acceptance of women in the war zones; and the relationship of these women to the places they encountered. Women's experience of and participation in the First World War is made complex by a number of factors.

Firstly, on the broader scale, as thousands of men were lost to the war or killed in action, women's lives changed drastically; the war period became a 
time of domestic upheaval, disruption to social class structures, and cultural change. Part of such changes was a re-emergence of the questions concerning gender roles and contested spheres of work and domesticity, now made necessary and urgent by practical circumstances.

Secondly, on the personal scale, women contributed to the war effort in ways too numerous to mention, from the sole management of home and family to the communal rolling of bandages or knitting of socks for soldiers in local village halls, and from the retraining in first aid, or as a military chauffeuse, to the joining of a women's corps such as the Voluntary Aid Detachment (VAD) or the Women's Army Auxiliary Corps (WAAC), and many more roles in between. This raised a number of personal issues for women who were very used to having their behaviour dictated by class expectations; there were now no clear guidelines as to how they should behave in their war effort. Should they be ladylike or business-like, and how should they dress, in uniform (which they could purchase) or practical work clothes? Women's literature of the First World War often reveals a tension between what was expected of women before the war and what became newly acceptable or redefined under the new circumstances of wartime conditions. Yet there is also a larger irreconcilable difficulty here: ideologically and in terms of propaganda for the men in the trenches, it was essential to maintain the image of women remaining passively at home, waiting patiently, maintaining the much-loved status quo as a significant part of the idealised "home and country" at stake in war. Inconceivable within this idealised image was the prospect of women, possibly in uniform, contributing to the war effort and also working hard to save their country. Simultaneously then, women were expected to be contributing to the war effort in some way whilst also accepting a more passive role embodying the image of those remaining stolidly at home, being fought for and thus giving the sacrifice at the front a purpose. This sense of conflicting roles for women was, of course, increased manifold for those women who were close to the front line, where their physical presence in the dangerous spaces of war was perhaps essential - say in the running of military hospitals - but ideologically disastrous. How could the soldier hero believe he was protecting his women folk if they refused to stay put at home and insisted on entering the war zones and encountering similar levels of danger to himself? At the very least this must have caused confusion and gender conflict regarding the ways women experienced the spaces of war. Nicola Beauman expresses the depth of this problem when she questions whether there was "any 'right' (that is acceptable) behaviour for the women who lived through the years of the Great War and for the heroines whom the writers among them recreated in their fiction". She goes on to make a list recording that it was wrong to be "smugly patriotic and pro-War. It was wrong to be too detached from it [...] 
wrong to indulge in complacent martyrdom. It was wrong to enjoy the war [...] wrong merely to devote oneself to one's children [...] It was right for men to go to war to fight for 'freedom', wrong for women to nurse or drive an ambulance to help to fight for the same freedom" (1993: 145-6). Participation in war for men can be largely seen as ideologically focussed on the single concept of the soldier hero. But for women it is more complex and much less well defined.

Thirdly, related to these conflicting roles and expectations for women in wartime, was the difficulty of finding a suitable mode of recording their experiences and encounters. This can be detected in the way women writers of the time struggled to reconcile ideological femininity with female participation in the war effort. Finding a mode of expression or appropriate tone which could encompass a sense of being protected by the masculine war effort as well as describing the authority of female war work, which also adhered to conventions of propaganda, masculine gallantry and the new feminism proved a challenge to many a fine female writer. But as Beauman claims, women's lives were "irrevocably changed" by the war, and so they had a right to respond (128, 146). Dorothy Goldman also argues that "women suffered differently" in war but because they were not part of the physical agony, their voices on the subject of war remained unheard. She warns of the potential danger of marginalising women because they remained true to their own experiences, thus denying a larger truth about the war (1993: 1-2).

May Sinclair was a writer who encountered the First World War from within the war zones, but experienced it in many ways as an outsider too. This divided engagement enabled an unusual approach in her particular mode of war writing, often taking the internalised (even psychologised) inner response to war and projecting this onto the exterior spaces of war situations. For Sinclair, with little else to offer the war effort besides her powers of observation, her writing prioritises her impressions of people and places over more factual commentary on military command or war action. In this way Sinclair's war writings, because of their unusual approach, start to investigate whether war zones could also be understood and imagined as female spaces. A close reading of Sinclair's war writing will help to dismantle a one-dimensional, masculinised domination of the story of the First World War. The intensity of feeling expressed not only in her diarised account but also in later novels is what sets Sinclair's war writing apart from other similar works. By concentrating on feelings, emotional responses and strong belief in female capabilities, she both participates in the war and yet remains outside the usual mode of discourse.

The women who did "talk of mud" had to find a means of expressing themselves. They had to determine their own tone and balance; make choices about what to include and what to omit, and constantly respond to the truth 
of their own war (Goldman 1993: 8). Any first hand discussion about the front by a woman writer was normally dependent upon the access arrangements she could make involving suitable transport and military permissions. War zones were variously open or closed to a female presence and participation depending on a range of variable and inconsistent factors. Sinclair's desperation to get to the front and her repeated accounts of favouritism and "luck" of other women getting to the front before her are testament to this. This link between Sinclair's eventual access to the front and the emotional honesty of her writing is a crucial one. Unlike other writers who never visited the war zones at the front, Sinclair's direct contact with the spaces of war gave her the confidence to write about the war as she experienced it and not as convention demanded.

On September 25th 1914 May Sinclair, a modernist writer aged about fifty, set off with Dr Hector Munro's ambulance corps, mostly made up of women, in order to provide assistance for the Belgian refugees. Although Sinclair had travelled abroad before, this trip to the front line offered her the opportunity to enter spheres not normally open to middle-age middle-class women, with no practical skills to offer. She certainly anticipated danger and excitement within the war zone. Suzanne Raitt has commented that Sinclair was one of those who were thrilled at the prospect of having her chance at the war (Raitt 1997: 78). Certainly the war had a marked impact on Sinclair's work: out of her day book, which recorded her experiences at the front, emerged her Journal of Impressions (1915a), and then a number of novels which refer to WW1 in various ways. Tasker Jevons (1916), The Romantic (1920) and Anne Severn and the Fieldings (1922) are the three which most closely echo her own experiences at the front, whereas Tree of Heaven (1917), Far End (1926) and History of Anthony Waring (1927) use the war more conceptually or as a backdrop for the narrative progression.

Some details of this expedition are clear, others remain curiously hazy. For instance, Sinclair recorded in her Journal the difficulties involved in even getting permission to travel to Belgium and the necessary badgering of embassies and the War Office. However, the funding for the venture is still open to speculation: Sinclair may have funded it all or just made a contribution, thus effectively buying her place. Even more intriguingly, we know from the Journal that Sinclair's time at the front only lasted fourteen days; yet the background to her return or dismissal remains a mystery. Sinclair's first biographer, Theophilus Boll, knew that Dr Munro "had requested the War Office not to allow her to rejoin the corps" and tried to get Munro to explain, but without success (1973: 107). Boll suggests that Sinclair "did not subordinate her strongly critical mind to the disciplinary phase of the military machine" (ibid.) and that Munro was not unreasonable in his request. Although Sinclair was witness to the way 
women worked in war zones, obeying orders and complying with military structures and bureaucracy, she personally seems to have found such a level of compliance almost impossible.

Nonetheless, the intensity of Sinclair's responses to war is clear from the level of emotional expression in her Journal and the way she reiterated the same material in subsequent novels. Other war diaries adopt a different tone: Louise Mack's account of being in Belgium at a similar time to Sinclair, but remaining in Antwerp during the German occupation, has a much more practical, daily survival feel to it; and the well-known A Hilltop on the Marne, also 1915, by Mildred Aldrich has the authority of a visual panorama of the battlefields. Sinclair's account differs from other accounts by being much more personal. She limits herself to her own particular boundaries of comprehension and interpretation; she focuses on women's stories, and almost never attempts to extend her discourse to a more expansive war commentary. In doing this she remained almost painfully true to her own experiences and responses; her honesty at times is uncomfortable. Although her Journal is self-indulgent, it is also unusually revealing and insightful, giving confident prominence to personal feelings, reactions and observations, and bringing to light the human aspects of war some would prefer to remain hidden.

Sinclair's diary is unusual in making the connection between psychical and physical landscapes. She offers neither practicalities nor overview, but she does make detailed links between the war zones she encountered and her emotional responses. As the diary progresses through its three hundred and thirty two pages, it becomes far removed from the sensible, de-sensitised, understated and sometimes ironic tone which became the standard (highly masculinised) mode of discussing the First World War (Fussell 1977: 29-35). Yet, from the outset, Sinclair does try to adhere to overarching propagandist conventions of foregrounding heroic behaviour, commenting positively on the war, and maintaining discretion about actual place names and people; she had after all signed Masterman's "Author's Manifeso", a propagandist agreement (Smith 2000a: 5). Her subversion lies in her unconventional subject matter and in her mode of expression, which borders on the experimental. Alongside a mapping of emotions onto war landscapes is the employment of modernist experimental literary techniques, particularly unusual in war writing. Sinclair uses the modernist techniques of fragmentation of consciousness, exploration of dreams and hallucinations, and surprising juxtapositions between matters large and small. She further disrupts her own text by presenting herself as an unreliable narrator and achieves this by digressing and contradicting herself, by playing with time and sequence, and by making clear links between inner and outer worlds. All this sets her journal apart from other writers who, in writing about war, 
reverted to a realist mode. In literary terms then, Sinclair was both within the modernist fold, but outside the normative style of war writing.

Critics have varied in opinion on this war diary. Sinclair's contemporary Rebecca West saw it as a work of sincerity, "one of the few books of permanent value produced by the war" (Marcus 1982: 305). Later, Claire Tylee has described Sinclair's war journal as self-indulgent and self-absorbed, even "narcissistic and myopic" but nonetheless genuine (1990: 30). Sharon Ouditt has described Sinclair as "rapidly seduced by the alterative glories of warfare" and as one who "articulates her excitement in hedonistic terms" (1994: 34). Suzanne Raitt argues that Sinclair's writing embodied the shame of being a woman in the war zone, and goes on to describe Sinclair's many humiliations: her sexual jealousy of other women finding favour with officers; her lack of medical training; her lack of understanding of war; her excitement at danger; and "the shame of a middle-aged woman who sees in middle-age her last chance at life" (1997: 65). Sinclair's war journal has variously been found to be both within the canon of war literature and outside acceptable discourse about the Great War. Whilst Tylee has argued that Sinclair indulged a Victorian penchant for ecstatic expression concerning war, I suggest that while there are moments of heightened emotion, the Journal is best understood overall as a modernist text -one which exhibits modernist literary techniques and uses the devices associated with this mode to explore the internal response to war.

Sinclair's role as secretary to the commandant, publicity officer and fundraiser (which she claims she was partly goaded into taking), combined with her excitement at the prospect of war, and her personal determination to "help out" during her war adventure, without a proper role or any medical skills to offer, all in all made her position a precarious one (1915a: 16-17). It also made her acutely sensitive regarding the entry of women into the various arenas of war, their treatment and their behaviour, their participation and exclusion from the obvious and less palpable spaces of war. Some issues and incidents, recorded initially in her Journal, were reworked at length into her later novels. Within this context, Sinclair brought her interests in feminism and emerging psychological discussions to bear on her attempts to rationalise and understand the chaos of war and the different aspects of life it affected. As Sinclair entered each new war zone she did so in the spirit of adventure, anxiously awaiting opportunities to come her way. With each new zone, her writing reveals attempts to accept and understand her often complicated relationship to that space. She negotiates between the external space and her internal emotional response, often using one to explore the other. At times her intense excitement is at odds with the brutal realities of war. Always her negotiation with war spaces is filtered through the strangeness of being a woman at war, amongst an ambulance crew unusually 
made up of a large number of women. Thus Sinclair's is a highly individualised representation of war expressed through a gendered, internalised and often analytical response, and situated in a surprising range of war zones.

The Journal may be read as a woman's negotiation with the internal and external spaces of war. Moreover, Sinclair is also at war with her conscience over her presence in the war zone, and her sense of being somewhere she has no right to be is a dominant preoccupation. On arriving at Ostend after five weeks of what Sinclair describes as "black funk" (a terrible fear of what she might encounter), and when a moment of spare time presents itself, Sinclair uses the opportunity to "sneak into the Cathedral" and then again she "wanders forth" to look at the "motor ambulances on Cockerill's Wharf" (1915a: 8-10). Later she enjoys the beauty of the Flemish landscape, with its low vividly-painted houses, straight roads and tall trees (1915a: 11-12). Sinclair experiences this space as a tourist and is even accused of sight-seeing by one of the nurses in the ambulance corps $(9,10)$. She is not without a guilty conscience about this, but finds it difficult to conceive of this beautiful place as a war zone. The discrepancy between her previously imagined "limbs entangled in intestines, corpses by every roadside" and her actual experience of the beautiful peace of the open countryside is vast (1915a: 8). Her imagined war zone and her first experience of Belgium are diametrically opposed, and Sinclair has to temper her obvious excitement, "Is it possible that I am enjoying myself?" with her awareness of the disapproval of others (1915a: 12). Her honesty in including this in her Journal, in discussing the thrill which turns into ecstasy, her enjoyment of the sights and the drive to Ghent enable us to understand one of the incongruities of this war. At this moment in the Journal the war-torn Belgium is described as a tourist venue, and the spatial images of war-zone and Flemish landscape are awkwardly juxtaposed. The idea that a country at war might at once encompass touristic landscapes and war-torn villages and battlefields is an arresting juxtaposition and raises questions about privilege and non-combatants. At the very least, Sinclair's first-hand observations of her surroundings refute a totalising image of a country at war.

Once at Ghent, Sinclair is struck by the effectiveness of the conversion of a rather grand hotel, the Flandria Palace Hotel, into a military hospital: "the billiard-room is an operating theatre; the great dining-hall and the receptionrooms and the bedrooms are wards" (1915a: 23). It is where they are to set up their quarters and whilst Sinclair had expected "two bare dormitories", they are given "a fine suite of rooms" (1915a: 21). She describes their mess-room in detail with French windows and a balcony and a "pale blonde light" that fills the room. However, this interior space, with its marble-topped tables set out for conference in a $U$ shape, becomes an oppressive place for Sinclair. As they wait for 
orders Sinclair understands that they are to confine themselves patiently to the mess-room, and she resentfully reflects that it is a space "to contain us" (1915a: 28). When some of the corps do have the "luck" to go out in the ambulance to the rescue of some injured soldiers, Sinclair becomes increasingly aware of the divisions of space in the hospital and the qualifications and permissions needed to enter into the different sections. After the chosen crew has left, Sinclair does seem to spend some time sitting in the deserted mess-room, possibly sulking, until she strikes up a conversation with one of the hospital orderlies and asks if she could hand round some cigarettes to the patients. Sinclair thus leaves the confines of their quarters and enters the designated spaces of the hospital, sheltered and somewhat protected by the orderly, who, "with his instinct of protection [...] glides before me, smoothing the way between my shyness and this dreaded majesty of suffering"( 1915a: 46). Sinclair compartmentalises her emotions spatially within this hospital: in the mess-room she rails against her inactivity and uselessness, and in the wards she has to deal with her fear and the imagined horrors of physical mutilation and pain she may witness. But as she follows the orderly through the wards she feels she is "in another world", feeling not horror as she expected, but a humbled "adoration" (1915a: 47). Back in the mess-room again, she becomes miserable once more and watches with longing the movement of vehicles rushing towards the "fighting lines" (1915a: 49). Within the building of the hospital and nearby to the front lines, Sinclair is tantalisingly close to significant war zones, and yet kept apart by the mandates of required skill-sets and military appropriation of different spaces in wartime.

Frustrated at the confines of the mess-room, Sinclair negotiates a role for herself, helping out with the thousands of refugees at the Palais des Fêtes serving at the evening meals for three hours. She describes the vast building as "rather like Olympia" (1915a: 61), and whilst this might in the past have been a venue for horticultural shows, now "It is the peasants, the men and women who tilled these fields and their children that are being shown here" (ibid.). Sinclair's shock at the sight of so many displaced families and individuals is clear from her unusually controlled and detached way of commenting on the refugees: "four thousand of them lying on straw"; "laid out in rows"; "litter of prostrate forms" (ibid.). Sinclair explains how she feels "stunned and stupefied" by the sight of so much human sorrow and destitution and seems so overwhelmed that her usual emotional responses have not yet come to the surface. ${ }^{1}$ The most she can do is to repeat a phrase as a sine qua non, which only inadequately accounts for what she has seen, "'C'est triste, n'est-ce pas?"' whilst she tries to account for this numbness: "And you who look at them cannot speak or think or feel" (1915a: 63-9).

1 Claire Tylee has argued that this moment evades Sinclair's powers of description. 
When it comes to the evening meal service, the spatial organisation and manipulation of so many pitiful refugees enables Sinclair's emotional state to come to the fore. She describes the layout of the makeshift mass dining arrangements in some detail, with the "enormous oblong space" of the Inner Hall and its "immense auditorium, tier above tier of seats" at either end (1915a: 84 ). She describes how the refugees "come in relays to be fed" down a gangway of ropes in an ordered, measured fashion. For Sinclair it is these temporary barriers, and the way they control the crowd, that make these thousands of people less threatening for her. "The barriers make it a steady procession, a credible spectacle. You can take it in" (1915a: 85). As she assists with the serving of the coffee and slice of plain white bread, she works herself into a frenzy, bypassing the established system of serving the coffee, and turning the washing up into a competition: "You contend with brawny Flemish women for the first dip into the tub and the driest towel. Then you race round the tables with your pile of crockery, and then with your jug, and so on over and over again" (1915a: 87). At night she has a nightmare in which people are plucking at her sleeve and pleading for more food. The order and structure given by the physical barriers help Sinclair deal with the chaos of so many displaced people, but when in close proximity to them she is barely able to control her pity or herself, perhaps imagining that through some superhuman effort of racing round the tables manically she would be able to alleviate the unbearable misery. Thus, although the refugees are controlled by the spatial arrangements, Sinclair is not.

During an evening's visit to the local Hôtel de la Poste, Sinclair decides that she must move from the Hospital Quarters and take a room in this War Correspondents' hotel for a week. It is the energy of this alternative place close to the action, as opposed to the apathy of the corps's quarters at the hospital, which attracts Sinclair and gives her renewed enthusiasm for one of her objectives as war reporter. Her aim with this shift of venue is to "write some articles" and she anticipates at least having her ear closer to the action here, "The War Correspondents will tell me what is being done", even if she actually gets physically no closer to the battlefields (1915a: 111). She is attracted to the seeming liveliness of the hotel, which is full of correspondents and Belgian officers, "It is full of live, exultant fighters, and of men who have their business not with the wounded and the dying but with live men and live things, and they have live words to tell about them" (1915a: 107). The Flandria seems to have made her feel inactive and imprisoned, "a prisoner in a Hotel-Hospital", whilst she anticipates more productivity and energy at the Poste (1915a: 109). Even though her new room "is more like a prison than any view from the "Flandria"' Sinclair still makes the move (1915a: 112). She has already met a sculptor she knew before the war, someone who also came from "the world where people make busts and 
pictures and books" (1915a: 106) and so associates the new location with a different mindset, a more active outlook, and more direct contact with the war.

In some ways this move works out well for Sinclair, but it also highlights personal difficulties. She enjoys her new freedom to wander around the town and particularly enjoys the old quarter and the cathedral, with no-one to accuse her of sight-seeing this time. With this newly acquired freedom, Sinclair does indeed find inspiration enough to write a few articles. There is a stark contrast for Sinclair between the sense of inhibiting imprisonment she felt at the hospital-hotel and the freedom and buzz she absorbs at the journalists' hotel. In the Flandria, she was restricted as part of the corps, trapped in the mess-room of their designated quarters and forced to wait for permission to do anything worthwhile. For not only did Munro and his corps become part of the bureaucratic system, and necessarily have to wait for their orders to leave for the front; when those orders did come in Munro very much presided over the decision over who would go and who would stay. His recklessness in taking the young and attractive Ursula Dearmer (Lady Dorothie Fielding in real life) with him to the front line seems to have infuriated Sinclair. The now broken promise made to Ursula's mother to keep her daughter out of danger is part of Sinclair's annoyance, but Sinclair's envy and even sexual jealousy is what leads her to argue so ferociously with Munro (Raitt 1997: 79). Sinclair does not shy from revealing heightened emotions and fraught human relationships in her impressions of the effects of war.

Quite purposefully Sinclair offers the reader few general overarching signposts for the progress of war; it is hard to gauge a sense of the progress of military operations from her text. She frequently operates the convention of using only the first letter of a proper noun to conceal a significant place name. Moreover, she disrupts her own text, and footnotes her confusion about the sequence of days, using malaria fever as a reason for the discrepancy and also as a way of excusing her aggressive and accusatory behaviour towards Munro. The reader is able to understand the German invasion of Belgium from vague snippets only. Furthermore, quite surprisingly for a day book of such a limited period, she has to reconstruct its linearity and does so deliberately within the text and footnotes. In this way her modernist non-realist technique and her concentration on linking her inner world to the outer one succeed very well in conveying the chaos of war. The story of Sinclair's time at the front in terms of places, dates and specific battles has an unreliable feel. In part this is due to temporal confusion and in part due to an unevenness of tone and the excessive attention to seemingly insignificant domestic or personal issues such as her fuss over a writing table. In stark contrast to this her portrayal of her own experiences rings true. She is conscious of her inappropriate placement in this 
space of war, and yet desperate to make the most of her time there. This can be read through her mixed-up behaviour. For instance, when installed in the Hôtel de la Poste, even though she is desperate for information, she initially tries to conceal herself beyond a glass screen from the one journalist she knows, "Mr L", and she does this to avoid making an "infernal nuisance" of herself (1915a: 121-2). Nonetheless, when they meet at breakfast the next day, Sinclair evidently pumps him for all the information he can give her about the war.

Although Sinclair produced a few war-time articles such as "The Woman at the Front" (1915b), her output was limited. Her lack of writing productivity may be initially linked to the inertia and imprisonment she felt at the Flandria, but is also more complex: there are many instances where she is reluctant to make copy out of her experiences and numerous times when she prioritises her emotional response over the facts of an event. In addition, she knows there are things which shouldn't be passed on as they are either confidential or would subvert British propaganda on the home front. Given this, it is easy to see why her impressions of the war did not easily translate into newspaper copy. Although her Journal indicates that she is excited by the prospect of a great journalistic scoop (1915a: 104), it seems to be those most directly involved in the war that she admires the most, and this idea of charging round the front lines rather than using contemplative writing skills is explored much more in Tasker Jevons, her war novel.

Sinclair was also sensitive to the restrictions placed upon her as a woman. She was impressed by the work of many women she met at the front and comments accordingly. For example, the two women originally with Sinclair's corps who went on to manage a vital triage and dressing station and became known as "the two Heroines of Pervyse" (Mitton 1916); and the hospital totally staffed by women and run by Mrs St. Clair Stobart; and although the details are hazy - was it a converted concert hall or a convent? - Sinclair manages to convey a good deal about the conditions for the patients and the dedication of the allfemale staff, concluding that "this Hospital is a Feminist Show" (1915a: 147-51).

Sinclair's use of the idea of feminism and what she terms "the New Chivalry" become fused into a mode of understanding women's entry and acceptance into various war zones. ${ }^{2}$ Sinclair uses the term feminist about Hector Munro, describing him as a "curious psychic monster" taking women with him to the "siege-guns" at the front line. She questions, "Is it uncanniness? Is it obstinacy? Is it dreamy innocence? Or is it some gorgeous streak of Feminism? Is it the New Chivalry that refuses to keep women back, even from the firing-line? The New Romance that gives them their share of danger?" (1915a: 111-2). Whilst The Romantic became the title of one of her war novels, it is this term the "New

2 For another discussion of Sinclair and chivalry see Wilson (2003: 179-88). 
Chivalry" which Sinclair uses, sometimes quite ironically, to discuss the opportunities given by whichever masculine authority (Munro or other) to women to travel within the war zone. For instance, "The General-he cannot have a spark of the New Chivalry in his brutal breast- has ordered Mrs. Torrence off her chauffeur's job" and of one of the ambulance corps, "the chauffeur Tom has none of the New Chivalry about him. He is the mean and brutal male, the crass obstructionist, who grudges women their laurels in the equal field" (1915a: 113-4). Sinclair is particularly conscious of Tom, the chauffeur, and Munro, the corps leader, as gatekeepers of her freedom to enter the war zones. Those who determine her ability to venture to the front line are measured against the New Chivalry. Once she assumes what she believes to be the newly-authoritative role of war correspondent she feels a newly-found impetus to travel and her show of independence is followed by a few permissions from Munro to go out in the car and then the ambulance. Tom, the chauffeur, is a frequent barrier to Sinclair's entry into war zones. He is of the old school, takes no orders from a woman and shows his disapproval either by defying Sinclair directly and refusing to transport her, or by questioning how he is "to steer his car and protect his women at the same time?” (1915a: 237). Other men adopt more equivocal positions on the question of women at the front, "'Mr. L.' may have disapproved of 'taking a lady into danger"', but did not restrict Sinclair's movements in any way in the war zone (1915a: 178).

This contact, Mr. L., and the comings and goings of the Hotel lead Sinclair closer to the war zones. She has a number of excursions both with the ambulance corps and with others and each time records her different impressions, albeit haphazardly. Because it was impossible for Sinclair (and perhaps anyone in truth) to grasp a broader sense of the war, she relates what she witnesses in terms of the people and the places she encounters. On one errand to transport two doctors, the passengers see for themselves the mass exodus from Antwerp, and Sinclair describes this in terms of the landscape: "endless processions of refugees; endless, for the straight, flat Flemish roads are endless, and as far as you can see the stream of people is unbroken"( 1915a: 138). Another time on the road out of Baerlaere with "Mr L", Sinclair finds herself in a "joyous adventure" where the road is blocked by the ruins of a small hamlet. Her description of the ruined houses gives us an immediate sense of the devastation caused by the bombardment, and the wall of the barn was "the only thing that stood between us and the German batteries" (1915a: 176-7). This playful tone continues when Sinclair has to stop a fellow passenger from leaping out of cover "to find some pieces of nice hot shell for me" (1915a: 177). She stops him, not because souvenir hunting is distasteful, but in order to keep him out of danger. 
Sinclair, who largely led her life alone, enjoyed the prospect of comradeship in the ambulance corps; whether she functioned at all well as part of this group, or even recorded it accurately, has been hotly contested (Raitt 2000: 162-3). Nonetheless, it was important to Sinclair that she not only witnessed the war but that she did so with other people. And although some of those people restricted her access to the front, others made it possible not just to get there, but also to try and make sense of the incomprehensibility of it all. The various moments in this Journal in which Sinclair does feel connected and involved with the war are also times when others help her or share the experience. In this way Sinclair relies on what Patricia Yaeger describes as a "communal intimacy", which Yaeger goes on to explain, quoting Arendt, as "the presence of others who see what we see and hear what we hear". This "reassures us about 'the reality of the world and ourselves"' (1996: 1-38).

Her connections with places and people at the front helped her to make at least some sense of the chaos of her war. The reality of spaces in the war zone was significant for Sinclair. She discusses the concept of philosophical reality in a number of contexts in her writing, including this Journal. On one mission to bring back the wounded from a small village near Lokeren, accompanied by two stretcher bearers, to her great joy she finds a badly wounded soldier in one of the houses. She becomes obsessively possessive about him, "to me he was the most beautiful thing I have ever seen [...] He was my first wounded man" (1915a: 196). The whole episode turns into something of a mystical experience for Sinclair, "There was something odd about that short stretch of grey road and the tall trees at the end of it and the turn. These things appeared in a queer, vivid stillness, as if they were not there on their own account, but stood in witness to some superior reality. Through them you were somehow assured of Reality with a most singular and overpowering certainty" (1915a: 193-4). The sense of finally doing the task she had secretly hoped for all this time, recovering the wounded from the front line and virtually under fire, is given epiphanic status. She bestows her belief in philosophical Reality upon the physical manifestation of the surrounding landscape.

Through her various trips and her earnest but largely inconsequential efforts to offer "help", she locates her time in Belgium within the detail and reality of her immediate surroundings. She attaches emotional significance to various places, often displacing her emotional reaction onto those places. Her regret at the whole war is expressed when they pick up wounded from a convent in Ecloo, where time has stood still for centuries and Sinclair is charmed by the life there. It is as though in this place alone there was opportunity for psychic rest. Something in the calmness and order of the convent allows her a momentary pause to contemplate the larger destructive force of the war in 
general, seeing the threatened invasion as "a horror of the Middle Ages" (1915a: 306). Similarly, at the end of her trip, when Sinclair is manipulated into returning to England, she associated her very great disappointment with the white cliffs of Dover, "And I hate the white cliffs. I hate them with a sudden and mysterious hatred"(1915a: 331). Even afterwards Sinclair continued to project her emotions and responses to war onto the places she encountered in her travels. In her poem "After the Retreat", written in the style of the Imagists, she mournfully displaces and anthropomorphises the sadness of Belgium onto a house: "It looked / Through windows blurred like women's eyes that have cried too long" (1915c). Yet because this house is the destination of her night-time flights of fancy, there is a sense that Sinclair also maps her deep regret at being forced out of the war onto the topography of the same house, making it represent both the fall of Belgium and the hurtful curtailment of her own war. The house, standing for this longing of Sinclair's, speaks the disappointment she can hardly name.

Of all the ways in which Sinclair could have presented an account of her short time in Belgium in the First World War, she positions it meticulously and determinedly as a journal of "impressions", stating that she has no intention of producing a factual diary or social commentary, or general record of field ambulance work (1915a: ix). ${ }^{3}$ She doesn't want her account to be "second-hand" (1915a: xi) and announces her intention of including her "temperament" - her emotional experience and internal response as an untrained but intelligent female observer. In this way the text does not function as a conventional, factual war narrative, but as a series of fragmented impressionistic sketches. Moreover, there seem to be deliberate strategies to make the text unreliable. The overtly-stated sincerity and authenticity of tone with which the Journal is written masks a number of factors: the Journal itself was not written at the front and Sinclair comes close to admitting that it was not even written directly from daily notes; it underwent several full revisions before the final version was sent for publication (Raitt 2000: 160-61). And for an acclaimed and highly professional writer, there are a large number of amateurish oversights, such as the unevenness of pace, the periods of sketchy detail, the "lost" days of Sinclair's illness, the confusion over place names and the unconsciousness of time, with much footnoting and questioning of accuracy. Sinclair uses her authorial control, either consciously or unwittingly, to construct a wartime self of an unreliable narrator. Two selves are present: the self that witnesses the front (the narrator); and the self that writes and edits these impressions later with a meta-narrative of self-judgement (the author). Her extensive explanation of her method seems to be an excuse for her infelicities and an apologia for

3 Although she did try to offer some more factual accounts in her few newspaper articles later. 
her self-indulgence, but also an attempt to find a tone of voice that might help explain the effects of war on the emotions of a sensitive woman. For Sinclair, the problem of writing about her experience of the places of war will not be moulded into a conventional form and structure. The question arises why such a competent and professional writer would produce such a haphazard account. Why has authenticity and reliability been subsumed into another project? If her only desire was to reproduce the frantic, disorganised and chaotic nature of war, then Sinclair could have used her novelist's powers of description. By producing such a disrupted narrative, Sinclair can be seen to be, on the one hand, conforming to agreed standards of propaganda, and on the other, producing a non-conformist female perspective of war. Rebecca Hogan has argued for the diary form as a subversive, écriture féminine style of writing (Hogan 1991 99-100). Seen this way, the Journal's fragmentation and unreliability, its focus on the inner life and emotional responses, and its constant reference to the women workers at the front, all combine to disrupt masculinist conventions of fact, linearity, rational explanation and purpose. ${ }^{4}$ Sinclair has thus found a way to be both within the war, but outside its conventions.

It is her engagement with the places and spaces of the different war zones which enables her to write a war narrative at such odds with convention. Place becomes a catalyst for stating the truth of her experience. By rooting her war continually in a sense of place, albeit a mess-room, an hotel, a hospital or a battlefield, she can explore the underside of war experience, the greed for adventure, the petty bureaucracy, the limitations put on women, the achievements and the arguments among those women, the incongruous beauty of the war zone, the Reality at the front, and so on. All the while she manages not to be bound by the conventions of "positions of batteries and the movements of armies" (1915a: x) in her writing and to focus on the bravery and heroism of women, resisting the masculine totalising one-dimensional image of the First World War.

In her war novels Sinclair continues her themes of being both involved with the war and yet set apart from its normal constructs and modes of conveying meaning. The focus on the inner life in a time of physical brutality gives Sinclair the critical space and distance to explore the adjunctive aspects of war. Unusual, even distasteful, aspects of war such as the pursuit of personal glory; cowardice and psychosis; hostility and competition between women at the front; and war neurosis all feature in her war fictions.

Tasker Jevons, the eponymous hero of Sinclair's first novel after A Journal of Impressions, is a gifted writer who, without the security of class and position,

4 See Sharon Ouditt's discussion of Woolf's war writing, which I have found helpful here (Ouditt 1994: 169-71). See also Angela K. Smith's discussion of a "different kind of female language for the literary representation of war" (Smith 200ob: 3 ). 
becomes very successful. Attracted to him is an intelligent and spirited upperclass girl with a disregard for social propriety, and through Viola and her family the novel explores the cruelty and hilarity of English pre-war snobbery. Shortly after the outbreak of war, Jevons takes himself, his chauffeur and his much loved and now khaki-painted car to the front line in Belgium (1916: 266-71). The reason for the writer's being at the front is a poignant theme for Sinclair, and perhaps her thoughts about her own position had crystallised when she wrote of Jevons in the novel, "I don't want to go out to the war to write about it. I want to do things"' (1916: 262). Jevons, then, in his self-purchased khaki, eschews the idea of merely reporting the war and opts for a more directly involved participation as a rescue worker, with himself and his chauffeur picking up injured soldiers from the front line in Belgium. This rejection of the writing career and the driving around the battlefields reflects Sinclair's ambition to do something useful in the practical sense. There is a desire to engage more directly with the war zone, to engage with it physically as a bodily presence rather than intellectualising the war and engaging only with the mind (and the pen). In this novel Sinclair directly recycles much material from the Journal, from the hotel name and layout to the restrictions imposed by being under orders, from speculations and conversations about the war to actual events and places such as battlefields, besieged villages and a convent. Jevons's bravery earns him the respect and admiration of those other elite men of action: the "officers of the General Staff" (1916: 293). Viola, who through her persistence catches up with Jevons, witnesses "through the glass screen" the scene of "public homage" to him by the officers for entering the most dangerous zones in his scouting car, under fire, to rescue the wounded (1916: 293-94).

Viola herself, through persistence and negotiation works her way into front line danger for some of the time too, and echoing the Journal there is a discussion about women entering the war zone. Viola responds to a comment made about chivalry in a way "that drove her back in sheer defence on a Feminist line. She said that nowadays women had chivalry too" (1916: 317). The war zones, as Sinclair observed them in life and in fiction, were open or closed to rescue workers not just in the most obvious way, according to their gender, but in a more complex way, which depended on female chivalry, bravery and determination as well as on the powers of persuasion of the women involved.

Her next war novel, The Romantic (1920), very much focusses on bravery and cowardice, and follows two characters, John and Charlotte, in an uneasy relationship, out to the front in Belgium amongst a voluntary ambulance corps. In this work of fiction the places and spaces of war which Sinclair encountered in real life become a direct means of expressing an interior psychological landscape of psychosis, misogyny and cowardice. Using her interest in the new 
psychoanalysis, and her connections with the Medico-Psychological Clinic of which Hector Munro was a founding doctor (Boll 1962: 310-26), Sinclair explores the link between the physical circumstances of war and the more abstract science of psychology. The story of John's cowardice is exposed against a detailed backdrop of different war zones.

Once at the front, the novel focusses on the spaces of war as Sinclair previously experienced them and on how these spaces provide an opportunity for airing aspects of human emotions not normally associated with more conformist accounts of war-time behaviour. Competitiveness, for instance, comes to the fore over the allocation of quarters to volunteer groups. At the Flandria military hospital (taken directly out of the Journal, even with the same foolish statue above the staircase), the group learn that their field ambulance crew will have to share quarters with another corps. Once in the quarters (with the same glass door and blonde light) the corps already in situ is possessive about the space, making no room for the new arrivals. As the groups get their turn on the battlefield, John's cowardice comes to notice as he drives away in the ambulance without the wounded, or refuses to carry the stretcher and runs away round the turn of the road with its "curving screen of trees" (1920: 101, 123). Whilst the landscapes of the battlefield help to mask John's acts of cowardice, the different interior spaces of the quarters function as places for disclosure and reflection on his behaviour. The psychotherapist, Dr. McClane, quite likely a portrait of Hector Munro, discusses John's illness with Charlotte in her bedroom, away from the public area of the mess-room. And when Charlotte needs time on her own to come to terms with his cowardice, she tries to hide from general view on the balcony, but is brought back into the group, back into the mess-room. They all now know how John has behaved, and by making room for her to sit down, they offer her their support. The different spaces of the mess signify private and public understanding and acknowledgement. And as John's behaviour becomes public knowledge, so it is increasing talked about in the joint public space of the mess, and then in open spaces: John and Charlotte's final conversation is in Convent Garden as he is trying to bolt from the war; and McClane's final resume of John's condition (voicing Sinclair's psychoanalytical explanation) takes place on the deck of the boat taking them back to England. This final space of the novel is a transitional space moving between war and real life back home, a space in which to try and make sense of the events of war.

Anne Severn and the Fieldings (1922) is the last novel of Sinclair's which has the First World War as a central focus. In some ways Anne Severn is perhaps Sinclair's most sophisticated attempt to account for the war in terms of the interior mental and psychological experience, intricately mapped out against places and spaces. 
Through the character of Anne, yet again a member of an ambulance corps in Belgium, Sinclair revisits her never-forgotten rancour at her dismissal from the front. When Colin, one of the Fielding brothers, develops a bad case of war neurosis, it is Anne his cousin and not Queenie his wife (also a member of the same corps), who is sent home to look after him. In the fictionalised version of Sinclair's own tale, Queenie manipulates the situation so that Anne is fired "out of the Corps" (1922: 114-7). In the character of Queenie we see the unpleasant pursuit of female glory again with this woman bossily dominating the ambulance corps and greedily seeking all the action in the war zone. Yet Sinclair wreaks her revenge, and Queenie is portrayed as over-bearing and domineering, reviled by Colin and objectified as part cause of his nervous terror. Anne, on the other hand, matures in personality and looks, takes over the running of the cousins' family estate and devises a multi-faceted, holistic approach to bringing Colin back to full mental health.

Just as in other novels Sinclair used the war zones to explore heightened emotions and psychological issues, so in Anne Severn she uses the domestic interior and peace-time exteriors to portray the topography for a return to mental health. Anne's home-made strategies for curing Colin depend upon the layout and spaces of the house and farm for their success. It is as if the interior battle against war neurosis can only be fought back in the familiar territory of the domestic space, using the actual rooms of the house and fields of the farm as a map for mental recovery. Inter-connecting bedrooms with doors left open, the terrace and the library, become places where Colin spends his time, shivering, screaming and remembering the horrors of war (1922: 120-1). Anne resists her father's instruction to send Colin to a nursing home and instead she effects a programme of revisiting the places of their childhood. Slowly, through a combination of memory and place, he starts to recover. His final recovery has to take place outside the confines of the farm, in Sicily in fact, where the "beauty of the place" gives him the sense of inner peace he so craves (229-30). Perhaps following Sigmund Freud's metaphor of the mind as a house, Sinclair explores the effects of the newly-prominent shell shock in terms of the interior of the house and his recovery in terms of exterior places. Whereas Freud really used the house only abstractly as a metaphor for the mind, Sinclair's approach is perhaps more easily understood as a technique after the Symbolists, or even the Imagists where the thing stands for the idea, as in this case the house stands for Colin's mental landscape. There is something of a displacement of the effects of shell shock onto the layout of the house. In this novel the war is on the inside, in the mind, in the home; the cure lies in being able to face the exterior.

Sinclair's negotiations with the places and spaces of her short time with a field ambulance corps are to be understood in terms of her personal encounter 
physically and psychologically in those zones. Her Journal of Impressions remains an intriguing document because of its first hand emotional response (from someone who was never in any real danger) together with its depth of insight and commentary. An apparatus of modernist techniques is employed to bypass convention and expose the aspects which concern Sinclair most of all. By locating her experiences so directly - in hospital, hotel or refugee centre and by "placing" her self in the context of war, Sinclair's journal reveals much concerning the experience of a non-combatant in the First World War. By the very use of places and spaces to signify her responses, by melding the external location with an internal psyche, Sinclair, neither truly inside or outside the war, negotiates an alternative voice to enrich our understanding of women, consciousness and war.

\section{Bibliography}

Aldrich, Mildred. 1915. A Hilltop on the Marne: Being Letters Written June 3-September 8, 1914. London: Constable.

Beauman, Nicola. 1993. "It is not the place of women to talk of mud": Some Responses by British Women Novelists to World War I' in Goldman, Dorothy (ed.) Women and World War I: The Written Response. London: Macmillan: 128-49.

Boll, Theophilus. E. M. 1962. 'May Sinclair and the Medico-Psychological Clinic of London' in Proceedings of the American Philosophical Society 106 (Aug): 310-26.

- 1973. Miss May Sinclair: Novelist: A Biographical and Critical Introduction. Cranbury, New Jersey: Associated University Presses.

Fussell, Paul. 1977. The Great War and Modern Memory. Oxford: Oxford University Press.

Hogan, Rebecca. 1991. 'Engendered Autobiographies: The Diary as a Feminine Form' in Prose Studies: Special Issue on Autobiography and Questions of Gender 14 (2, Sept): 95-107.

Mack, Louise. 1915. A Woman's Experiences in the Great War. London: Fisher Unwin.

Mitton, G. E. (ed.). 1916. The Cellar-House of Pervyse: A Tale of Uncommon Things from the Journals of The Baroness T'Serclaes and Mairi Chisholm. London: A \& C Black.

Ouditt, Sharon. 1994. Fighting Forces, Writing Women: Identity and Ideology in the First World War. London: Routledge.

. 2000. Women Writers of the First World War: An Annotated Bibliography. London: Routledge.

Raitt, Suzanne. 1997. “Contagious Ecstacy”: May Sinclair's War Journals' in Raitt, Suzanne and Trudi Tate, (eds) Women's Fiction and the Great War. Oxford: Oxford University Press: 65-84. . 2000. May Sinclair: A Modern Victorian. Oxford: Oxford University Press. 
Sinclair, May. 1915a. A Journal of Impressions in Belgium. London: Hutchinson.

. 1915b. 'The Woman at the Front: A Wild Spirit of Adventure Awakened' in Daily Chronicle (2 February 1915).

. 1915c. 'After the Retreat' in The Egoist 2 (1 May): 77.

. 1916. Tasker Jevons: The Real Story. London: Hutchinson.

1920. The Romantic. London: Collins.

.1922. Anne Severn and the Fieldings. London: Hutchinson.

. 1919. The Tree of Heaven. London: Cassell.

1926. Far End. London: Hutchinson.

1927. History of Anthony Waring. London: Hutchinson.

Smith, Angela. K. 200oa. Women's Writing of the First World War: An Anthology. Manchester: Manchester University Press.

. 20oob. The Second Battlefield: Women, Modernism and the First World War. Manchester: Manchester University Press.

Tylee, Claire. 1990. The Great War and Women's Consciousness: Images of Militarism and Womanhood in Women's Writings, 1914-64. Iowa: University of Iowa Press.

West, Rebecca. 1982. 'Miss Sinclair's Genius' in Jane Marcus (ed.) The Young Rebecca: Writings of Rebecca West 1911-17. London: Macmillan: 304-07.

Wilson, Leigh. 2003. "She in her 'Armour' and He in his Coat of Nerves"' in Heilmann, Ann (ed.) Feminist Forerunners: New Womanism and Feminism in the Early Twentieth Century. London: Pandora: 179-88.

Yaeger, Patricia. 1996. 'Introduction: Narrating Space' in Yaeger, Patricia (ed.) The Geography of Identity. Ann Arbor: University of Michigan: 1-38. 